\title{
Profil genetika DNA mikrosatelit kromosom-Y masyarakat laki-laki soroh Kayuan Pasek Catur Sanak Bali Mula
}

\author{
I Ketut Junitha, Ni Luh Watiniasih, \\ dan Ni Luh Putu Ria Puspitha \\ Universitas Udayana \\ Email:
}

\begin{abstract}
Abstrak
Tulisan ini mengkaji tentang profil genetika masyarakat soroh Kayuan yang termasuk dalam klan Pasek Catur Sanak Bali Mula menggunakan marka DNA mikrosatelit pada kromosom Y. Gen-gen atau DNA pada kromosom Y diturunkan secara patrilineal dari ayah hanya kepada anak lakilaki demikian seterusnya. Empat lokus DNA mikrosatelit yaitu: DYS19, DYS390, DYS393 dan DYS395 digunakan untuk mengamplifikasi DNA sampel dari sebanyak 67 orang probandus laki-laki masyarakat soroh Kayuan dari Desa Siakin, Songan, Blandingan, Kutuh Kecamatan Kintamani dan Desa Jehem Kecamatan Tembuku, Kabupaten Bangli. Hasil penelitian menunjukkan bahwa ditemukan sebanyak 12 ragam alel dari semua lokus yang digunakan dengan keragaman genetik yang rendah hanya sebesar $0,33 \pm 0,001$. Berdasarkan kombinasi alel-alel semua lokus ditemukan profil genetik laki-laki sebanyak 12 haplotipe yang didominasi oleh haplotipe 1 sebesar 0,39 diikuti oleh haplotipe 2 sebesar 0,16, haplotipe 7 sebesar 0,12 dan haplotipe 6 sebesar 0,10 , sedangkan delapan haplotipe lainnya dengan frekuensi kecil-kecil. Ditemukan profil DNA pada laki-laki soroh Kayuan sama dengan profil DNA pada soroh Celagi sesama klan Pasek Catur Sanak Bali Mula yaitu haplotipe 6 yang merupakan haplotipe dominan pada soroh Celagi karena adopsi, sedangkan untuk haplotipe 5 sama-sama dengan frekuensi rendah yang mungkin akibat mutasi.
\end{abstract}

Kata kunci: Soroh, DNA mikrosatelit, kromosom-y, haplotipe, alel.

\footnotetext{
Abstract

This research is conducted to find out the genetic profiles of Kayuan clan which is belong to Pasek Catur Sanak Bali Mula, indigenous Balinese people. The DNA profiles is
} 
identified by using Microsatellite DNA of Y chromosome. Genes or DNA in Y chromosome are descended from father to son (patrilinealism). Four loci of microsatellite DNA from Y chromosome are used, including DYS19, DYS390, DYS393 and DYS395 to amplified DNA samples from 67 males probands. The probands are people of Kayuan clan from Siakin, Songan, Blandingan and Kutuh villages, Kintamani sub district and others are originally from Jehem village, Tembuku sub district, Bangli regency. The research found 12 allele varieties from all the analyzed loci, which resulted in low genetic diversity $(0.33+0.001)$. There are 4 combinations alleles of 4 loci that created 12 various haplotypes, the greatest one is haplotype $1(0.39)$, followed by haplotype 2 $(0.16)$, haplotype $7(0,12)$ and the smallest one is haplotype $6(0,10)$. On the other hand, eight other alleles found on the smaller frequencies. Two similar allele combinations were also found on DNA profiles of Celagi clan, which is also belong to the similar family, Pasek Catur Sanak Bali Mula. The two allele are haplotype 6 and 5 found in both, Pasek Kayuan and Pasek Celagi. The haplotype 6 as dominant allele of Celagi clan by adoption, haplotype 5 however, the frequency was the lowest. This allele only detected in one member of each clan due to mutation.

Keywords: Clan, Microsatellite DNA Y Chromosomal, haplotype, allele

\section{Pendahuluan}

Wasyarakat Bali sekarang ini telah berkembang sejak dari za1 man prasejarah yang datang dari Cina, India, Jawa Tengah atau pun Jawa Timur (Covarrubias 1956; Bellwood 1985; Ardana, 1996; Ardika 1996). Kedatangan orang-orang dari berbagai tempat tentunya juga akan diikuti oleh masuknya berbagai macam genetik maupun budaya yang selanjutnya membentuk struktur genetik tertentu dan juga akulturasi budaya pada masyarakat Bali sekarang ini (Breguet et al. 1982; Lansing et al. 2004; Karafet et al. 2005).

Akulturasi antara budaya lokal, yaitu penghormatan terhadap leluhur dengan budaya yang menunjukkan jati diri dari penguasa Majapahit membentuk kelompok-kelompok masyarakat berdasarkan garis keturunan (geneologis) yang disebut klan atau di Bali lebih dikenal dengan soroh. Terbentuknya soroh-soroh di Bali 
ditandai dengan dibangunnya pura utama/pusat masing-masing soroh seperti pedharman-pedharman di kawasan Pura Besakih dan Pura Kawitan di berbagai tempat di Bali yang merupakan pura pemujaan bagi masing-masing Soroh (Soebandi, 1981). Setiap anggota dari masing-masing soroh meyakini merupakan keturunan dari leluhur yang sama. Kesamaan leluhur pada setiap soroh akan ditunjukkan oleh kesamaan atau kemiripan secara genetika. Kesamaan genetika antaranggota soroh dapat dilihat dari profil DNA-nya karena hubungan kekeluargaan seseorang ditunjukkan oleh kesamaan profil DNA-nya yang penurunannya dari generasi ke generasi tidak dipengaruhi oleh faktor lingkungan. Penanda DNA mikrosatelit biasanya digunakan dalam melihat hubungan keluarga seseorang yang biasa digunakan dalam forensik (Junitha dan Alit, 2011; Junitha, 2012).

Penanda genetik mikrosatelit yang merupakan bagian DNA yang tidak mengkode untuk sifat-sifat apa pun sangat baik digunakan untuk melihat perbedaan genetik antarindividu maupun kelompok masyarakat karena tidak berkaitan dengan baik buruknya karakter seseorang. Dengan penanda ini manusia disamakan atau dibedakan hanya berdasarkan profil DNA-nya dan tidak berkaitan dengan kualitas hidup maupun kedudukannya di masyarakat. Penanda genetik mikrosatelit banyak digunakan untuk studi variasi genetika antar populasi (Weber and Wong 1993; Bowcock et al., 1994; Slatkin, 1995). Mikrosatelit kromosom-Y yaitu DNA yang hanya terdapat pada kromosom $Y$ dan diturunkan hanya dari laki-laki ke anak laki-laki saja sehingga secara genetika hanya berkaitan dengan garis keturunan (geneologis) dari ayah. Penanda mikrosatelit kromosom-Y sangat tepat digunakan untuk penelitian Soroh-soroh di Bali karena penentuan soroh seseorang didasarkan pada garis keturunan patrilineal atau garis ayah (Junitha, 2007). Penanda genetik mikrosatelit kromosom-Y telah digunakan dalam penelitian kasta-kasta di India (Mitchell et al., 2006), masyarakat Bali (Junitha, 2004; Karafet et al., 2005; Junitha dan Suryabroto, 2010) demikian juga untuk soroh (Junitha dan Sudirga, 2007; Junitha dkk., 2009; Junitha et al., 2012; Junitha and Watiniasih, 2014).

Tulisan ini merupakan kajian genetik masyarakat Soroh Kayuan berdasarkan DNA mikrosatelit kromosom-Y menggunakan empat pasang primer DYS19, DYS390, DYS393 dan DYS395 untuk mendapatkan variasi profil DNA laki-laki. Profil DNA hasil 
kajian digunakan untuk melengkapi database DNA klan-klan masyarakat Bali umumnya dan khususnya klan Pasek Catur Sanak Bali Mula yang meliputi yaitu; Kayu Selem, Celagi, Terunyan dan Kayuan (Riana 2011). Data base profil DNA masing-masing soroh dapat digunakan untuk dasar penelusuran kawitan secara ilmiah yang selama ini menggunakan penelusuran berdasarkan babad (Soebandi 1998) atau melalui nunas baos atau meberas jinah dari dukun yang di Bali disebut sebagai tapakan atau sedahan.

\section{Profil genetika DNA mikrosatelit kromosom-Y}

Penelitian pada tahun 2012 dilakukan pada Soroh Kayuan yang merupakan salah satu bagian dari klan Pasek Bali Mula atau Catur Sanak. Penelitian menggunakan empat penanda DNA mikrosatelit kromosom-Y yaitu lokus DYS19, DYS390,DYS393 dan DYS395. Profil DNA masyarakat laki-laki soroh Kayuan dilihat dari ragam alel serta haplotipe yang ditemukandigunakan untuk melengkapi database profil DNA klan-klan masyarakat Bali khususnya pada klan Catur Sanak hasil penelitian sebelumnya.

Dalam studi soroh Kayuan ini sebanyak 67 orang probandus laki-laki diambil sampel DNA-nya yang berasal dari Desa Siakin, Songan, Blandingan, Kutuh Kecamatan Kintamani dan desa Jehem Kecamatan Tembuku, Kabupaten Bangli, diperoleh sebanyak 12 ragam alel yaitu dua ragam alel pada lokus DYS19, masing-masing tiga ragam alel pada lokus DYS390 dan DYS393 serta sebanyak empat alel pada lokus DYS395. Ukuran ragam alel merupakan panjang DNA hasil amplifikasi sampel DNA probandus pada mesin PCR dalam satuan jumlah basa. Pada elektrogram dituulis sebagai pb seperti disajikan pada gambar 1a-d. Ragam dan frekuensi alelalel masing-masing lokus disajaikan pada (Tabel 1)

Tabel 1. Lokus, ragam alel dan frekuensinya

\begin{tabular}{ccc}
\hline Lokus & Ragam alel & Frekuensi \\
\hline DYS 19 & 200 & 0,967 \\
& 204 & 0,033 \\
DYS390 & 203 & 0,186 \\
& 207 & 0,763 \\
& 211 & 0,051 \\
DYS393 & 125 & 0,049 \\
& 129 & 0,705 \\
\hline
\end{tabular}




\begin{tabular}{lll}
\hline \multirow{2}{*}{ DYS395 } & 133 & 0,246 \\
& 115 & 0,034 \\
& 119 & 0,017 \\
& 127 & 0,220 \\
131 & 0,729 \\
\hline
\end{tabular}

Tingginya frekuensi alel 200pb pada Soroh Kayuan seperti yang tercantum pada tabel 1 merupakan hal yang wajar karena alel 200pb lokus DYS19 merupakan alel umum pada masyarakat Soroh Catur Sanak maupun masyarakat Bali umumnya seperti pada masyarakat Tenganan, Sembiran dan Triwangsa , Brahmana Siwa dan Budha( Junitha et al., 2012; Junitha dan Suryobroto, 2010; Junitha dkk, 2009; Junitha dan Sudirga, 2007; Junitha, 2004; Junitha and Watiniasih, 2014). Alel 200pb merupakan alel universal karena tersebar merata di seluruh dunia (Hammer et al., 1997; Ruiz-Linares et al., 1996; Hummer \&Horai, 1995).

Untuk Lokus DYS 390 frekuensi tertinggi pada alel 207pb dan merupakan hal yang wajar karena merupakan alel umum ditemukan pada masyarakat Bali. Alel ini dalam frekuensi tinggi juga ditemukan pada masyarakat Sembiran, Terunyan dan Tri Wangsa (Junitha dan Sudirga 2007) demikian juga pada Soroh Celagi (Junitha et al., 2012). Pada Soroh Kayu Selem, alel 211pb ditemukan frekuensinya lebih tinggi dibandingkan dengan alel 207 (Junitha dkk., 2009). Alel 211-219 tinggi ditemukan pada etnis Jawa, India Timur, China, Tailand, Aborigin Taiwan (Parra et al. 1999; Foster et al. 1998). Di India, alel 207pbdengan frekuensi tinggi ditemukan pada semua kasta (Ramana et al., 2001; Battacharyya et al., 1999).

Pada lokus DYS393 diperoleh sebanyak tiga alel yaitu: alel 125, 129 dan 133pb dengan frekuensi masing-masing 0,049, 0,705 dan 0,246 . Tingginya frekuensi alel 129pb pada masyarakat Soroh Kayuan berbeda dengan masyarakat Catur Sanak lainnya seperti Soroh Celagi dan Terunyan dimana alel yang tinggi frekuensinya ditemukan pada 133pb (Junitha et al. 2012; Junitha dan Sudirga 2007). Untuk lokus DYS395 ditemukan empat ragam alel yaitu 115, 119, 127 dan 131pb. Alel 131pb mendominasi di antara alel-alel yang ada. Frekuensi tinggi pada alel 131pb juga ditemukan pada masyarakat Soroh Celagi (Junitha et al., 2012).

Keragaman genetik paling tinggi ditemukan pada lokus 
DYS393 sebesar 0,447 $\pm 0,001$ diikuti oleh lokus DYS395 sebesar $0,433 \pm 0,001$, DYS 390 sebesar 0,387 $\pm 0,002$ dan paling kecil pada lokus DYS 19 sebesar 0,064 $\pm 0,002$. Rataan keragaman genetik pada soroh Kayuan sebesar 0,333 $\pm 0,001$ termasuk rendah dan rendahnya keragaman ini disebabkan oleh tingginya frekuensi salah satu alel dari masing-masing lokus. Dibandingkan dengan keragaman genetik pada sesama klan Catur Sanak keragaman genetik Soroh Kayuan menempati urutan kedua setelah Soroh Kayu Selem dengan keragaman genetik sebesar 0,511 \pm 0,031 dan keragaman Soroh Celagi sebesar 0,148 \pm 0,054 (Junitha et al., 2012; Junitha dkk., 2009; Junitha dan Sudirga, 2007).

Dengan mengkombinasikan alel-alel dari masing lokus secara berturutan dari lokus DYS19, DYS390, DYS393 dan DYS395 diperoleh sebanyak 12 ragam haplotipe. Dari data ini menunjukkan bahwa terdapat 12 macam profil DNA laki-laki atau kepurusa pada Soroh Kayuan. Data haplotipe, kombinasi alel dan frekuensinya disajikan pada Tabel 2.

Tabel 2. Haplotipe, kombinasi alel-alel dan frekuensi

\begin{tabular}{|c|c|c|c|c|}
\hline $\begin{array}{c}\text { Haplo- } \\
\text { tipe }\end{array}$ & $\begin{array}{r}\text { Kombir } \\
\text { DYS19, DYS390, }\end{array}$ & osi alel & DYS395 & Frekuensi \\
\hline 1 & $200, \quad 207$ & 129 , & 131 & 0,393 \\
\hline 2 & 200, & 129, & 127 & 0,161 \\
\hline 3 & 200, & 129, & 119 & 0,018 \\
\hline 4 & 200, & 125, & 131 & 0,018 \\
\hline 5 & 207, & 125, & 127 & 0,036 \\
\hline 6 & 207 & 133, & 131 & 0,107 \\
\hline 7 & 200, & 129, & 131 & 0,071 \\
\hline 8 & 200, & 133, & 131 & 0,125 \\
\hline 9 & 200 & 129, & 131 & 0,018 \\
\hline 10 & 200, & 129 & 131 & 0,018 \\
\hline 11 & 200, & 133, & 131 & 0,018 \\
\hline 12 & 207 & 129, & 115 & 0,018 \\
\hline
\end{tabular}

Haplotipe 1 dengan kombinasi alel 200,207,129,131 memiliki frekuensi paling tinggi sebesar 0,393 diikuti oleh haplotipe 2 dengan kombiasi alel 200, 207, 129, 127, haplotipe 8 dengan kombinasi alel 200, 203, 133, 131 yang memiliki frekuensi sebesar 0,125 dan haplotipe 6 dengan kombinasi alel 200, 207, 133, 131 dengan frekuensi sebesar 0,107. Haplotipe 5 dengan kombinasi 200, 207, 
125, 127 dengan frekuensi sebesar 0,036 dan frekuensi paling sedikit yaitu sebesar 0,018 terdapat pada haplotipe 3, 4, 9, 10, 11, 12. Dari 12 haplotipe hanya haplotipe 1 yang dapat ditemukan baik di desa Siakin sebagai tempat Pura Kawitan Soroh Kayuan, di desa Songan sebagai tempat awal terbentuknya sang Catur Sanak termasuk Soroh Kayuan dan di desa Blandingan yang letaknya tidak jauh dari desa Siakin. Melihat keberadaan dan frekuensinya yang paling tinggi patut diduga bahwa haplotipe 1 merupakan haplotipe original (asli/awal) dari Soroh Kayuan. Tiga dari empat haplotipe yang ditemukan di luar desa Siakin dan Songan ditemukan juga di desa Siakin seperti haplotipe 7 dan 6 yang terdapat di desa Blandingan, hal ini bisa dimengerti karena letak desa Blandingan dan Siakin tidak jauh. Hanya satu haplotipe yang ditemukan di desa Jehem Kecamatan Tembuku, Bangli tidak ditemukan baik di desa Siakin maupun Songan yaitu haplotipe 12 yang memiliki kombinasi alel 204, 207, 129, 115. Tujuh dari 12 haplotipe yang ada pada Soroh Kayuan yaitu haplotipe 1, 2, 3, 4, 5, 9 dan haplotipe 10 tersebar di desa Songan, lebih banyak daripada ragam haplotipe yang terdapat di desa Siakin. Hal ini dapat dimengerti karena desa Songan sebagai tempat pembentukan awal Soroh Kayuan akan memiliki variasi ragam alel yang lebih tinggi akibat adanya peristiwa mutasi. Banyaknya mutasi berkaitan dengan perjalanan waktu. Penanda mikrosatelit kromosom-Y memiliki kecepatan mutasi sebesar $10^{-3}$ per generasoi per gamet (Weber and Wong, 1993; Bowcock et al., 1994; Slatkin, 1995).

Dua ragam haplotipe pada Soroh Kayuan yaitu haplotipe 6 dengan kombinasi 200, 207, 133, 131 sama dengan haplotipe mayoritas (haploitpe 1) Soroh Celagi dan demikian juga untuk haplotipe 5 dengan kombinasi alel 200,207,125,127 sama dengan haplotipe 3 dari Soroh Celagi. Untuk haplotipe 6 soroh Kayuan dimiliki oleh warga dari desa Siakin dengan frekuensi relatif tinggi yaitu 0,107 dan hal ini mungkin disebabkan oleh adanya peristiwa nyentana dan juga adopsi. Sedangkan untuk haplotipe 5 Soroh Kayuan yang sama dengan haplotipe 3 dari Soroh Celagi mungkin hal ini disebabkan oleh mutasi konvergensi (menyatu). Untuk kejelasan dari kedua haplotipe tersebut perlu dilakukan analisis lebih teliti yaitu dengan cara menambah lokus yang digunakan serta melakukan PCR dan elektroforesis bersama antar individuindividu yang dengan haplotipe sama dari kedua soroh. 


\section{Penutup}

Dari hasil penelitian dan pembahasan di atas dapat disimpulkan bahwa pada Soroh Kayuan ditemukan sebanyak 12 ragam alel dan dari kombinasi alel-alelnya terdapat sebanyak 12 haplotipe. Dua haplotipe yaitu dengan kombinasi alel-alel 200, 207, 133, 131 dan 200, 207, 125, 127 memiliki kesamaan dengan haplotipe pada Soroh Celagi.

\section{Ucapan terima kasih}

Terima kasih kami sampaikan kepada masyarakat Pengurus dan Soroh Kayuan yang telah membantu dan bersedia secara sukarela sebagai probandus, Rektor Universitas Udayana dan LPPM Unud yang telah membantu pendanaan penelitian melalui dana penelitian PNBP Unud.

\section{Daftar pustaka}

Ardana I G G. 1996. "Kebudayaan Austronesia sebagai Dasar Kebudayaan di Indonesia (Suatu Analisis Arkeologi)." Dalam Ardika I W. dan I M. Sutaba (ed.), Dinamika Kebudayaan Bali. Denpasar: Upada Sastra, hlm. 43-56

Ardika I W. 1996. Bali dalam sentuhan Budaya Global Awal Abad Masehi. Dalam Dinamika Kebudayaan Bali. Dalam Ardika I W. dan I M. Sutaba (ed.), Dinamika Kebudayaan Bali. Denpasar: Upada Sastra, hlm. 57-72

Bhattacharyya, NP. Basu, P., Das M., Pramanik S., Banerjee R., Roy B., Roychoundhury S., and Majumder P.P. 1999. Negligible male gene flow across etnhic boundaries in India, revealed by analysis og Y-chromosomal DNA polimerphism. Genome Research. 9: 711-719.

Bellwood P. 1985. Prehistory of the Indo-Malaysian Archipelagio. Sydney: Academic Press.

Bowcock AM. Ruaiz-Linares A. Tomfohrde J. Minch E. Kidd JR. \& Cavalli-Sforsza. 1984. "High resolution of human evolutionary trees with polymorphic microsatellites." Nature. 368:455-457.

Breguet G. Ney R. Kirk RL. and Blake NM. 1982. "Genetic survey of an Isolated Community in Bali Indonesia. II. Haemoglobine Type and Redd Cell Isozymes." Hum. Hered. 32: 308-317.

Covarrubias M. 1956. Island of Bali. Alfred A Knopf. New Cork 
Foster P. Kayser M. Meyer E. Roewer L. Pfeiffer H. Benkmann H. and Brankmann B. 1998. "Phylogenetic Resolution of Complex Mutational Features at Y-STR DYS390 in Aboriginal Australians and Papuans." Mol Biol. Evol.15:1108-1114 .

Hummer MF., Spurdle AB., Karafet T., Bonner MR., Wood ET., Novelleto A., Malaspina P., Mitchell R., Horrai S., Jenkins T., and Zegura SL. 1997. "The Geographic Distribution of Human Y-chromosome Variation." Genetics. 145: 787-805

Hammer MF. and S. Horai. 1995. "Y-chromosomal DNA variation and the peopling of Japan." Am. J. Hum. Genet, 56:951-962.

Junitha IK. 2004. "Keragaman Genetik Masyarakat di desa-desa Bali Aga Berdasarkan Analisi DNA dan Sidik Jari." Disertasi. IPB. Bogor.

Junitha IK. 2007. “Penggunaan DNA Mikrosatelit untuk Penelusuran Kawitan pada Soroh-soroh Masyarakat Bali." J. Biologi XI(2): 5054

Junitha IK. dan B. Suryobroto. 2010. “Hubungan Genetika Pria Masyarakat Sembiran dan Tri Wangsa di Bali." Biosfera. 27(1) Januari 2010. hlm. 1-8.

Junitha IK dan SK Sudirga. 2007. "Variasi DNA Mikrosatelit Kromosom-Y pada Masyarakat Bali Mula Terunyan." Hayati. 14(2): 59-64

Junitha IK, SK Sudirga dan MD Sarawijana. 2009. “Variasi Genetik DNA Mikrosatelit Kromosom-Y Soroh Pasek Kayu Selem di Bali." Berkala Penelitian Hayati. Edisi Khusus No 3A Desember 2009.

Junitha I K. dan I. B. Alit. 2011. “Ragam Alel Mikrosatelit DNA Autosom Pada Masyarakat Bali Aga Desa Sembiran Kabupaten Buleleng Bali." Biota 16 (1) : 63-69.

Junitha IK, M. Phamawati and W Rosiana, “Genetic Diversity of Soroh Celagi (Pasek Catur Sanak Clan) Based on Y-Chromosomal Microsatélites DNA." Poster Presetation on 4th International Conferences on Biosciences and Biotechnology, Denpasar, Bali: September 20-21, 2012.

Junitha I K. 2012. "Peranan Analisis DNA dalam Penyelesaian Masalah Sosial di Masyarakat." Orasi Ilmiah. Pidato Pengukuhan Guru Besar Tetap dalam Bidang Biologi pada Fakultas MIPA Universitas Udayana. 20 Desember 2012.

Junitha I K, N L. Watiniasih dan I. A. M. Damayanti. 2014. "Struktur Genetik Brahmana Siwa dan Budha di Bali Berdasarkan DNA 
Mikrosatelit Kromoaom-Y." Proseding Seminar Nasional Sain dan Teknologi Universitas Udayana. Denpasar 18 -19 September 2014 ISBN. No: 978-602-294-018-0. Hal: 688-695.

Karafet, TM, JS. Lansing, AJ. Red, JC. Watkin, SPK. Surata, WA. Arthawiguna, L Meyer, M Bamshad, LB. Jorde, and MF. Hammer. 2005. "Balinese Y-chromosome Perspective on the Peopling of Indonesia: Genetic Contribution from Pre-Neolithic Hunther-Gatherer, Austronesia Farmer, and Indian Trader." Human Biology, Februari. Vol.77 (1): 93-113

Lansing S. AJ. Redd, TM. Karafet, IW. Ardika, SPK. Surata, JS. Schoenfelder, M. Campbell, AM. Merriwether, MF. Hammer. 2004. "An Indian Trader in Ancient Bali." Antiquity. Vol 78 (300):287-293

Mitchel RJ. BM Reddy, D Campo, T Infantino, M Kaps and M H Crawford. 2006. "Genetic Diversity Within a Caste Population of India as Measured by Y-Chromosome Haplogroups and Haplotypes: Subcates of Golla of Andhra Pradesh." Am.J. Phys. Anthrop. 000;1-9

Parra E. MD Shrivers., A. Soemantri., ST McGarvey., J. Hundrieser., N Saha., and R. Deka. 1999. "Analysis of Five Microsatellites Loci in Asian and Pasific Populations." A.J.Phy.Anthrop.110:1-16

Ramana GV, Su B, Jin L, Singh L, Wang N, Underhill P \& Chakraborty R. 2001. "Y-Chromosom SNP haplotypes suggest evidence of gene flow among caste, tribe, and the migrant Siddi population of Andhra Pradesh, South India." European J. Hum Genet. 9: 695-700

Riana I K. 2011. Lelintihan Sang Catur Sanak Bali. Kayu Selem, Celagi, Tarunya, Kaywan Balingkan, Warga Bali Aga. Denpasar: Yayasan $\tan$ Mukti Palapa Bali.

Ruiz-Linnares A. K Nayar, DB Goldstein, JM. Hebert, MT. Seilstad, PA. Underhill. AA.Linn, MW Felmen and LL. Cavali-Sforza. 1996. "Geographic Clustering of Human Y-chromosome haplotype." Ann Hum Genet. 60: 401-408.

Slatkin M. 1995. "A Measure of Population Subdivision Base on Microsatellite alleles Frequencies." Genetics. 139: 457-462

Soebandi, IK. 1981. Pura Kawitan/Pedharman dan Penyungsungan Jagat. CV. Kayumas. Denpasar.

Soebandi, IK. 1998. Mengenal Leluhur dari Dunia Babad. Denpasar: BP.

Weber J. and C. Wong. 1993. "Mutation of Human Short Tandem Repeats." Hum. Mol. Genet. 2(8): 1123-1128. 